\title{
MÉSZÁROS ZSOLT
}

\section{Női hálózatok és a 19. századi divatlapok}

\author{
A Magyar Bazár és olvasóközönsége*
}

A szakirodalomban közismert a sajtó térbeli és az ettől elválaszthatatlan szóbeli dimenziója. Az újságot behálózó szóbeli érintkezések - a pletykáktól, a társalgáson át a vitákig - visszavezethetők városi közösségi terekre. Erre utalnak például a korai folyóiratcímek, mint a lipcsei Das Courieuse Caffee-Haus zu Venedig (1698), a milánói Il Caffè (1764-1766), vagy a korabeli Európában mintaadónak számító angol Spectator (1711-1712), amelynek esszéihez a képzeletbeli Spectator Club szolgáltatta a keretet. ${ }^{1}$ Később, a piacosodás kibontakozásával a hasonlatokban felbukkan az áruház képe is. Mallarmé 1892-ben úgy beszél a hírlapok tárcarovatairól, mint sugárutak csillogó kirakatú boltjairól. ${ }^{2}$

Ezek mellett a sajtóhoz, azon belül is a napilapokhoz füződő legelterjedtebb képzettársítás a politikai nyilvánosságot jelképező parlament. Ez Habermas nyomán vált széles körben bevetté a médiatörténeti kutatásokban. ${ }^{3}$ Médiafogalma a polgári nyilvánosság univerzális modelljén, a politikai szólásszabadságon, a társadalmi egyenlőségen, a történelmi haladás emancipatorikus eszméjén és a politikailag aktív polgárok, vagyis a „tulajdonosok” közösségén alapul, ezáltal pedig - ahogy bírálói rámutattak - kizárt más társadalmi csoportokat (nők, munkások). A nyilvánosság alatt olyan küzdőteret ért, ahol azonos státuszú emberek között politikai, racionális érveken alapuló kritikai vita zajlik. Ennek kialakulásában kitüntetett szerepet tulajdonít a napilapnak, meglátása szerint a politikai nyilvánosság fejlettségét „,a sajtó és az állam közti vita állásán mérik”. ${ }^{4}$ Benedict Anderson, a nacionalizmus-kutatásokra nagy hatást gyakorló „elképzelt közösség"-elméletében arra a megállapításra jut, hogy a nyomtatott-kapitalizmus (saját

* Jelen közlemény a Wohl-nővérek irodalmi, kultúraszervezői és újságírói munkásságát feldolgozó disszertációm egy részletének átdolgozott változata.

${ }^{1}$ Briggs, Asa, Burke, Peter, A média társadalomtörténete, Gutenbergtöl az internetig, ford. Göbölyös Magdolna, Konok Péter, Gelléri Gábor, N. Kiss Zsuzsa, Bp., Napvilág, 2012 (2. bőv. átdolg. kiadás), 39-40.

2 Mallarmé, Stéphane, Étalages (The National Observer, 11 juin 1892) = Uö, CEuvres complètes II., szerk. Bertrand Marchal, Paris, Gallimard, 2003, 221.

${ }^{3}$ Habermas, Jürgen, A társadalmi nyilvánosság szerkezetváltozása, Vizsgálódások a polgári társadalom egy kategóriájával kapcsolatban, ford. Endreffy Zoltán, Bp., Gondolat, 1971.

${ }^{4}$ Uo., 91. - Ugyanakkor figyelmeztet a médiakereskedelem vagy az államhatalom káros befolyására (bulvárosodás, cenzúra), amely háttérbe szorítja a nyílt és értelmes eszmecserét. 
nyelv, tömegesedés) teremtette meg a nemzet fogalmi kereteit. Ebben a folyamatban a napilapoknak komoly közvetítő, alakító szerepet szán azáltal, hogy az olvasásukat olyan elsajátítási/tanulási folyamatként írja le, amely során az egyén szimbolikusan a nemzet részévé válik. ${ }^{5}$

Habermas és Anderson nyomán a nyilvánosság, a napisajtó és a nemzet fogalma összekapcsolódott. A médiakutatók a modern nyilvánosság részeként, mint annak helyszíneinek (kávéház, klub, parlament) kiterjesztéseként értelmezik a hírlapot, amelyhez a joggyakorlást és -védelmet, az állampolgári részvételt, a nemzetbe való betagozódást rendelik. A napi sajtóhoz való hozzáférés azonban nem volt mindenki számára szabadon elérhető. Számtalan példát találunk a korabeli forrásokban azokra az aggodalmas erőfeszítésekre, a tiltások és cenzúrák különböző formáira, amelyekkel a nőket igyekeztek távol tartani a napilapoktól. ${ }^{6}$

Több feminista kutató hívta fel arra a figyelmet, hogy a „modern” maszkulin norma köré szerveződik a szakirodalomban, azaz olyan cselekvésekkel jellemzik, mint a szabad városi térhasználat, vagy a napilapolvasás. Médiatudományi- és történeti megközelítéseik lebontva a dichotómikus felosztást, a magán- és a közszféra viszonyának összetettségét hangsúlyozzák. Yuval-Davis a nemzeti-politikai diskurzusokba bevonva a habermasi értelemben vett intimszférát, a nők jelentőségére mutat a nemzetépítés folyamatában. ${ }^{7}$ Ő a nacionalizmus három vonulatát különböztette meg: népnemzet, amelyben a nők biológiai reprodukció alanyaiként fontosak; kultúrnemzet, amely a nőkre a nemzetközösség jelképeiként, kulturális értékeinek átadóiként tekint; államnemzet, amely az állampolgári jogok gyakorlásában különböző szerepet szán nőknek és férfiaknak. A szerző mind a „nőiség”-et mind a „nemzet”-et időben és térben változó kategóriaként fogja fel, amely több tényező (pl. életkor, osztály, etnikai hovatartozás, ideológia, intézmény) függvénye. Analitikus szinten megkülönbözteti az államot, a civil társadalmat és a családot, mint három különálló, ugyanakkor egymással kölcsönösen függésben álló társadalmi és politikai területet. Érvelése szerint a nők a közösség biológiai és kulturális értelemben vett hordozói, újratermelői, valamint a kultúra szimbolikus határőrei. Erre a funkcióra, hogy egy korabeli magyar forrást idézzünk, a Divatsalon szerkesztői üzenete is utal: „Kegyed már a második, aki azt kérdi: illik-e egy lánynak politikai lapot olvasni, azért, mert a hazáját szereti? A hazáját szeretni persze, hogy »illik«, politikai lapot azonban - éppen ebből az okból - teljesen felesleges olvasni. Olvasson kegyed magyar történelmet, olvassa Jósika és Jókai regényeit, olvassa Tompát, Aranyt, Vörösmartyt, Petőfit

5 ANDERSON, Benedict, Elképzelt közösségek, Gondolatok a nacionalizmus eredetéröl és elterjedéséröl, ford. Sonkoly Gábor, Bp., L’Harmattan-Atelier, 2006, 42.

${ }^{6}$ Vö. Lyons, Martyn, A 19. század új olvasói: nök, gyermek, munkások= Az olvasás kultúrtörténete a nyugati világban, szerk. Guglielmo Cavallo, Roger Chartier, ford. Sajó Tamás, Bp., Balassi, 2000, 355.

7 Yuval-Davis, Nira, Nem és nemzet, ford. Szabó Valéria, Szentmiklósi Tamás, Bp., Új Mandátum, 2005. 
azért, mert hazáját szereti. Ki olvassa hát akkor ezeket, ha a nők is vezércikkeket olvasnak?!"8

Delap, DiCenzo és Ryan szerzőhármasa szintén a nyilvánosság habermasi fogalmának kritikai újragondolása mellett érvel annak érdekében, hogy láthatóvá és tanulmányozhatóvá váljon a nők társadalmi tevékenysége. ${ }^{9}$ Véleményükre támaszkodva a magyarországi helyzetre vonatkozóan is megállapítható, hogy, bár a nők ki voltak zárva a politikai döntéshozatalból, de osztályhelyzetüktől függően részt vettek a 19. század folyamán az oktatásban, a munkaerőpiacon, az egyleti és a szalonéletben, illetve a különbözö társadalmi mozgalmakban. Ehhez a sorhoz illeszkedik a női sajtó, amely további színteret biztosított a nők aktivitásának.

Pintér Györgyihez hasonlóan, aki a társadalomtörténeti, médiatörténeti, szociológiai, piaci és gender szempontok bevonásával a reformkori divatlapok újraértékelésére tett kísérletet, abból indulok ki, hogy a divatlapok a női olvasók széles rétegeit megcélozva, nyilvánosságot teremtettek számukra. ${ }^{10}$ Jelen tanulmányomban a 19. század utolsó harmadának vezető magyar divatlapjának számító Magyar Bazárt veszem szemügyre abból a szempontból, hogy divatlapként egyrészt milyen viszonyt ápolt előfizetőivel, másrészt milyen módon alakította ki, és müködtette számukra a nyilvánosság kereteit. ${ }^{11}$

\section{Az olvasóközönség}

Nehezen megragadható egy lap példányszáma, mert a kiadók üzleti titokként kezelve, nem hozták nyilvánosságra a terjesztési mutatókat, a közvetett források adatai pedig töredékesek, és a nem egységes kategóriarendszerből adódóan különbözők, ezért, ahogy arra számos kutató figyelmeztet, ezeket a számokat kellő kritikával és összehasonlítással kell kezelni. Ovatos becslések a postai összesítések, adóhivatali kimutatások, hirdető irodák katalógusai, korabeli sajtóstatisztikák, elszórt levéltári anyagok (pl. kiadóvállalatok, pénzintézetek fondjai), visszaemlékezések, levelezések alapján tehetők. ${ }^{12}$

${ }^{8}$ A szerkesztö postája, Lélia = Divatsalon, 1894, 23, szeptember 1., 31.

9 DiCenzo, Maria, Delap, Lucy, Ryan, Leila, Feminist Media History, Suffrage, Periodicals and the Public Sphere, Basingstoke, Palgrave Macmillan, 2011, 22. A könyvről szóló magyar nyelvü recenzió: CzEFERNER Dóra, Feminizmus és médiatörténet, avagy az angol nömozgalom megosztottsága = Klió, 2014, 2, 80-90.

10 PINTÉR Györgyi, Sajtókutatás - divatlapkutatás. A reformkori divatlaptörténet-írás esélyei = Médiakutató, 2013, 4, 42.

11 A Magyar Bazárt 1866-ban alapította Szabó Richárd (1820-1873). Halála után a Wohl-nővérek vették át a lap szerkesztését. Vö. NAGYDIÓsı Gézáné, Magyarországi női lapok a XIX. század végéig = Az Országos Széchényi Könyvtár Évkönyve 1957, Bp., 1958, 212-214; MÉszáros Zsolt, A modernitás és az emancipáció határvidékén, A Magyar Bazár irodalmi vonatkozásai a Wohl-növérek szerkesztése alatt (1873-1901) = Acta Academiae Paedagogicae Agriensis, Irodalom a sajtóban, szerk. Buzinkay Géza, Eger, Líceum, 2012, 27-35.

12 Vö. BuzinkaY Géza, Újságok és újságolvasók Ferenc József korában = Magyar Könyvszem- 
Grosz Viktor összesítése alapján 1885-ben a Magyar Bazárt 6000 példányban, összehasonlításképpen a saját müfajában a Hölgyek Lapját 1700, a Budapesti Bazárt 3000 példányban nyomták, a napilapoknál pedig a Pesti Naplót 9000, a Budapesti Hírlapot 16000 példányban küldték szét. ${ }^{13}$ Ezek alapján a Magyar Bazár középlapnak és vezető divatlapnak számított a magyar sajtópiacon, és úgy tünik, a 19. század végéig megőrizte támogatottságát. ${ }^{14} \mathrm{Az}$ Egyetértés munkatársa is úgy fogalmazott, a lapot majd harminc éven át sikeresen szerkesztő Wohl Janka (18431901) nekrológjában: „Divatlapja [Magyar Bazár] messze túlszárnyalta a többi divatlapokat és az első helyet méltán vívta ki és foglalta el a többiek között". ${ }^{15}$

Az előfizetők száma azonban az előfizetési (negyed-, fél- és egész éves) időszakokkal összefüggésben hullámzott, amit olyan tényezők is befolyásoltak, mint az évszakok. Például a hírlapok szempontjából a nyár holtidénynek számított, mivel az országgyülés szünetelt, míg az ősz és a tél - eseménydússága és időjárási körülményei miatt - serkentőleg hatott az újságolvasási kedvre. ${ }^{16}$ Ez utóbbi időszakokban más laptípusoknál szintén megugrott a sajtófogyasztás, még, ha ez nem is vont maga után feltétlenül előfizetést. Szép Ernő Dali dali dal (1934) címü regényében az apa karácsonyi szünidőre a Körből, illetve ismerősöktől visz haza olvasnivalónak Vasárnapi Újságot, feleségének Magyar Bazárt, a gyerekeknek ifjúsági lapokat. Jól ismert a sajtókutatók körében, hogy az előfizetők száma nem egyezik az olvasókéval, hiszen az egyes számokat be lehetett szerezni könyvkereskedésekből, házalóktól, vagy az illető egyszerüen kölcsönkérte valahonnan. Ez utóbbi elterjedt gyakorlatra világít rá a fenti regényjelenet, illetve $A$ Hét egyik közleménye a „Heti posta” rovatban: „,hetenkint egész utcasorokon végig egyik családtól a másikhoz vándorol »A Hét«-nek az az egy példánya, melyre az ottani kaszinó előfizetett" ${ }^{17}$ A kaszinók, társas körök, kávéházak sajtókínálata- és fogyasztása azonban - a hiányos dokumentációik-

le, 2003, 3, 386. - A Magyar Bazárt is kiadó Athenaeum esetében fennmaradtak az ülések jegyzőkönyvei, amelyekben 1870 nyár végéig külön napirendi pontban rögzítették lapjaik veszteségeit, nyereségeit, aktuális előfizetőik számát. Utána ez megszünt, és csak annyit jegyeztek meg szűkszavúan, hogy felolvassák a Hírlapok könyvét.

${ }^{13}$ Grosz Victor, Hazánk hirlapjai a budapesti Országos Általános Kiállitáson 1885-ben, Bp., Benjamin Manó, 1885, 13.

${ }^{14}$ A szerkesztői üzenetben arra hivatkozva intették türelemre a grafológiai rovatra váró olvasóikat, hogy hatezer előfizetőnek van joga beküldeni írást. Magyar Bazár, 1893, 2, január 16., boríték

15 Egyetértés, 1901, 141, május 24., 5.

${ }^{16}$ Az előfizetések visszaesését a nyári politikai uborkaszezonnal magyarázták az Athenaeum ülésén. Athenaeum Igazgatósági jegyzőkönyvek, 31. i. sz., választmányi ülés jegyzőkönyve (1869. aug. 26.), Z 723 Gazdasági Levéltár, MNL; A Magyar Újság vidékieket megszólító hirdetése pedig így kezdődött: „Az őszi és téli szezon beálltával minden magyar család előfizet valamelyik fővárosi napilapra, hogy szabadidejét hasznos és tanulságos szórakozással tölthesse el." A szerkesztő postája. Újságolvasóknak = Divatsalon, 1894, 2, október 15., 31.

${ }^{17}$ Heti posta, Pancsova, Rajongó = A Hét, 1891, 49, december 6., 799. 
ból adódóan - máig felderítetlen területnek számít, annak dacára, hogy ezek az intézmények jelentős előfizetők voltak. ${ }^{18}$

A divatlapok esetében az intézményi megrendelők közül kiemelkednek a nőnevelő intézetek, ahol nem annyira olvasnivalóként, hanem oktatási anyagként használták azokat. Például a pápai állami polgári leányiskola kézimunka óráin a Magyar Bazár mintáival dolgoztak. ${ }^{19}$ A győri állami tanítónőképző növendékei is a Magyar Bazár mintáit használták azon a kézimunka-kiállításon, amit a győrvidéki tanítóegylet nagygyüléséhez kapcsolódóan rendeztek. ${ }^{20}$ Zalaegerszeg képviselőtestülete az elemi leányiskola igazgatójának megkeresésére elrendelte az intézmény részére a Magyar Bazár és a Budapesti Bazár meghozatalát. ${ }^{21}$ A Magyar Bazár szerkesztősége rendszerint hivatkozott arra, hogy ipari iskolák is haszonnal tanulmányozhatják a kézimunka mellékleteket, amelyeket tanfolyamokként határoztak meg. A szakszerüséget az előfizetői felhívásokban sem mulasztották el kidomborítani, miszerint a Magyar Bazár munkalapjai révén „nemcsak a családi körben, hanem iskolákban is hézagpótló és nélkülözhetetlenné válik". ${ }^{22}$

Az előfizetői bázis szélesítését szolgálták a nőszervezetekkel való együttmüködések. A Wohl-nővérek korábbi, önállóan indított lapja, a Nök Munkaköre az Országos Nőképző Egyesület, a Magyar Gazdasszonyok Országos Egyesülete és az Országos Nőiparegylet közös hivatalos közlönyeként rendszeresen tudósított tevékenységeikről. ${ }^{23}$ A Magyar Bazárban külön cikkek és az „Egyleti hírek" rovat közleményei informáltak felhívásokról, programokról, eseményekről, gyülésekről, valamint arcképekkel kísért portré-sorozatot szenteltek a fővárosi és a vidéki nőegyletek elnöknőinek. ${ }^{24}$ A Budapesti Bazár előfizetési felhívásaiban

18 LaKatos Éva, Sikersajtó a századfordulón, Bp., Balassi-OSZK, 2004, 138.

19 Állami Polgári Leányiskola értesitője, Pápa, 1893-1900.

${ }^{20}$ Magyar Bazár, 1878, 21, november 1., 162.

${ }^{21}$ Képviselötestületi ülés = Zalamegye, 1887, 6., február 6., 1.

${ }^{22}$ Felhívás elöfizetésre! = Magyar Bazár, 1899, 10, március 16., boríték

${ }^{23}$ Nem kizárólagos sajtóképviseletet, hanem szakmai együttmüködést jelentett a kor három legfontosabb magyar nőegyletével. A Nők Munkaköre nyilvánosságot biztosított számukra, cserébe Wohlék lapja súllyal és referenciával jelenhetett meg a piacon. Az Országos Nőiparegylet híreiről a Kánya Emília által szerkesztett Családi Kör is beszámolt. A nőegyletek müködéséről és történetéről lásd BorBíró Fanni, Budapesti nöegyletek 1862-1904 = A nők világa, Művelődés- és társadalomtörténeti tanulmányok, szerk. Fábri Anna, Várkonyi Gábor, Bp., Argumentum, 2007, 185-207; KéRI Katalin, Hölgyek napernyövel, Nök a dualizmus kori Magyarországon 1867-1914, Pécs, Pro Pannonia, 2008, 78-90.

${ }^{24}$ Hentaller Elma, Magyarország nőegyleteinek elnöknöi, A pesti jótékony nöegylet és a magyar gazdaasszonyok egyletének elnöknői [Damjanich Jánosné, Bohusné Szögyény Antónia, Zichy Paulai Ferencné] = Magyar Bazár, 1875, 1, január 1., 1-2; Hentaller Elma, A magyarországi nöegyletek elnöknői, A kolozsvári és zágoni nöegyletek elnöknői [Kriza Jánosné, Teleki Domokosné, Szentkereszty Stephanie, Bánffy Albertné] = Magyar Bazár, 1875, 17, szeptember 1., 129-130; H. E. [HentalleR Elma], Kühnel Ignácné, az országos nőiparegylet elnöke = Magyar Bazár, 1877, 1, január 1., 1-2; H...R E...A [HENTALLER Elma], Magyarország nőegyleteinek elnöknői, Az országos nőképzö-egylet és a budapesti izraelita nőegylet elnöknői [Veres Pálné, Teleki Sándorné, 
szintén hangoztatta, hogy figyelemmel kíséri a fővárosi és a vidéki nőegyletek munkáját, sőt 1888-tól az 1890-es évek közepéig a következő alcímet vette fel: Magyar gazdasszonyok-, szegedi és veszprémi jótékony nőegylet, a sümegi- és több nőegylet hivatalos lapja.

Az intézményi kapcsolatok mellett, a Magyar Bazár más divatlapokhoz hasonlóan a család számára nélkülözhetetlen voltát hangsúlyozta, a tanácsok, az olvasnivaló és a szolgáltatások (pl. megbízások teljesítése) szintjén. A képes hetilapok előfizetési felhívásai általában mellőzték a társadalmi osztályra való utalást, de mégis határvonalat húztak, amikor a „művelt hazai olvasók”-hoz fordultak pártfogásért. ${ }^{25} \mathrm{~A}$ Magyar Bazár sem tett másként, amikor a müvelt magyar nőközönségre hivatkozott, azon belül pedig minden korosztályra: „bő ismeretet meríthet az ifjú leány, a családanya, a háziasszony, a társaságban mozgó és hivatásos foglalkozásnak élő nő egyaránt". ${ }^{26} \mathrm{~A}$ felsorolás azonban új célcsoportot is megnevez, amelyet lapszerkesztőkként a Wohl-nővérek szólítottak meg elöször, még pedig a dolgozó nőket. Ez beleillett a lap nőemancipációs programjába (munkavállalás, oktatás), amelyre most csak röviden tudok utalni. A dolgozó nő kategóriának szerepeltetése valós és széles körben létező társadalmi jelenségre mutat, és deklarálta a középosztálybeli női egzisztencia- és életpályamodellekben bekövetkezett 19. századi változásokat. Maguk a szerkesztők is beletartoztak, hiszen egzisztenciájukat saját erőből teremtették meg. György Aladár, a Statisztikai Hivatal tisztviselője 1884-ben írott cikkében azt fejtegette, hogy a nők tanulási, illetve munkalehetőségeinek differenciálódása gyakorlati okra vezethető vissza, nevezetesen a megélhetésre, amelynek gondja sokakat érintett. Az 1880-as népszámlás adatait hozta fel példának, miszerint a 25. életévüket betöltött nök között 188834 hajadon, 776014 özvegy és 5894 elvált, „összesen tehát csaknem egy millió olyan nő volt, kiknek bizonyára felénél több azontúl családot már nem alkothat, $\mathrm{s}$ ha anyagi viszonyai nem engedik, maga kénytelen önfenntartásáról gondoskodni". ${ }^{27}$

Nehéz lemérni azt, hogy a képes hetilapok ténylegesen milyen földrajzi közegben mozogtak, visszatérő reklámszövegük szerint a Kárpátoktól egészen az Adriáig terjedt az olvasótáboruk. Ritka az olyan közlemény a 19. század végén, mint amilyet a Képes Családi Lapok tett közzé, amely összeszedte, hogy az új-

Bischitz Dávidné] = Magyar Bazár, 1878, 7, április 1., 49-50; H. E. [Hentaller Elma], Az Országos Nőképzö Egyesület jubileuma = Magyar Bazár, 1893, 7, április 1., 49-50; DessewFFy Emma, Szívről-szívhez [Lorántffy Zsuzsanna Egylet] = Magyar Bazár, 1897, 48, december 24., 202.

${ }^{25}$ Lipták Dorottya, Újságok és újságolvasók Ferenc József korában (Bécs-Budapest-Prága), Bp., L'Harmattan, 2002, 125.

${ }^{26}$ Felhívás elöfizetésre! = Magyar Bazár, 1896, 39, október 16., boríték.

27 György Aladár, Nönevelésünk = Magyar Salon, 1884. 4, 330; Ebben a témában még lásd GYÁNI Gábor, Női munka és család Magyarországon (1900-1930) = Történelmi Szemle, 1987-1988, 3, 366-378; Csoma Zsigmond, Az első női foglalkozási statisztika Magyarországon, A női emancipáció és az első részletes női népszámlálás = Nők a modernizálódó magyar társadalomban, szerk. Gyáni Gábor, Nagy Beáta, Debrecen, Csokonai, 2006, 181-205. 
ság városonként hány példányban járt. ${ }^{28}$ Ehhez a szerkesztőségi irattárakra lenne szükség, hogy egy-egy számból hány példányt nyomtattak, és a kiadóhivatal hová mennyit küldött. De a szakértők szerint ilyen archívum az országos lapoknál sem maradt. Lakatos Éva a sajtótermékek településenkénti megoszlásának becsléséhez a lapok szerkesztői postáiban, hírrovataiban, lábjegyzeteiben, vidéki tudósításaiban elszórtan fellelhető, helyi statisztikákat hívja segítségül. ${ }^{29}$ A Magyar Bazár esetében, a terjesztési terület körvonalazásához a nyílt tér bizonyult számomra értékes forrásnak. Ugyanis a borítékon található nyílt rovatokba beküldött kérdések, válaszok feladóinak sokszor ott szerepelt a teljes neve és a címe (legtöbbször csak a helység, de Budapest esetében gyakran az utca és a házszám is).

A borítékot csak előfizető használhatta, akinek a leveléhez mellékelnie kellett az előfizetői címszalagot. Terjedelmi korlátok miatt, nem tudott megjelenni valamennyi küldemény, a szerkesztők folyamatosan kérték a türelmet, és tiltakoztak a nekik tulajdonított részrehajlás ellen, mondván, mindenkiét közlik sorrendben. De tudunk arról, hogy rostáltak, ha ugyanarra többen rákérdeztek, vagy magántermészetünek ítélték az adott témát.

Ötévente gyüjtöttem ki azokat a neveket (jeligés és teljes névalakok), amelyek mellett feltüntették a települést. Az általam vizsgált időszeletek: 1878, 1883, 1888-1889, 1893-1894, 1899-1900. Az utolsó háromnál azért néztem együtt két évet, mert egy évfolyamnál nem lett volna elég mennyiség. Míg 1878-ban a listám mintegy 200 tételt tartalmazott, 1888-ban 70-80-at. Ez több okra vezethetö vissza: az 1880-as évektől megsokszorozódtak a jeligék, és kevesebben közölték nyíltan a címüket, inkább a szerkesztóségen keresztül bonyolították le az ügyleteiket, nem pedig a lap hasábjain. A rovat terjedelme is szükült, és a borítékot rövid írások (hírek, kertészeti tanácsok) vagy hirdetések foglalták el. Arra nem vállalkozhatom, hogy messzemenő következtetéseket vonjak le az adatsorokból, ahhoz a körülmények túlságosan esetlegesek, viszont a földrajzi, a település szerinti és az előfizetők társadalmi eloszlására vonatkozóan óvatos feltételezésekbe bocsátkozhatunk.

Az 1870-es évek elejétől az 1890-es évek közepéig a belső arányok nagyjából változatlanok. Erős bázisnak tünik a mezőváros, a falu, vagy az olyan település, amely nem rendelkezett postával (pl. Bag 1878: 2 különböző családnév). Mind az öt időszeletben felbukkanó települések között nem meglepö, hogy ott találjuk Budapestet, de rajta kívül vármegyei központok, illetve két kisebb város, Kiskunfélegyháza és Csongrád is szerepel. Az 1899-1900 évkör adatai azt mutatják, hogy a századfordulóra átbillent az arány, és számszerüleg több a városból, mint a faluból érkező közlemény, és kevesebben írnak posta nélküli községből (1883: 38, 1899-1900: 7), amely az infrastruktúra fejlődésével és az urbanizáció-

${ }_{28}$ Magunkról-lapunkról I-II. = Képes Családi Lapok, 1891, 14-15, április 5. és 12., 223., 239-240. Nem vették fel a statisztikába azokat a helyeket, ahová egy vagy kettő példány ment.

${ }^{29}$ Lakatos Éva csaknem negyven évet (1854-1893) vizsgálva, a lapok különböző közleményeiből kinyert számadatokból állított össze táblázatot, amely városonkénti eloszlásban ad hozzávetőleges képet az egyes lapok példányszámairól. LAKATOS 2004, i. m. 122-135. 
val magyarázható. A földrajzi eloszlást tekintve a következő látszik kirajzolódni. A Magyar Bazár az északi területeken volt a legelterjedtebb (Felvidék és a mai Észak-Magyarország), majd a keleti országrészeken (Erdély és Partium). Ha kisebb földrajzi egységekkel számolunk, akkor előfizetői sűrüségben a Dunántúl áll az első helyen, amelyet az Alföld követ. Elenyésző számban járatták a lapot néhány nem magyar lakta településen a horvát és az osztrák részeken.

Vajda Viktor Az olvasásról, különös tekintettel postáink járására címü 1875ben megjelent cikke szerint irodalomra legtöbbet a következő rétegek áldoztak: kisbirtokosok, tanárok, írók, müvészek, jobbmódú gazdatisztek, magyar iparosok. ${ }^{30}$ A Magyar Bazár olvasótáborának bázisát - a borítékról kigyűjtött, azonosított személyek alapján - szintén a középréteg, és azon belül a vidéki lakosság alkotta: múzeumigazgatók, segédtanítók, jószágigazgatók, helyi birtokosok, ügyvédek, gyógyszerészek, lelkészek, egyetemi tanárok, mérnökök anyái, feleségei, lányai, valamint tanítónők, postai-távirdai alkalmazottak, kisdednevelők. De nemcsak birtokosok, hivatalnokok vagy értelmiségiek járatták a lapot, hanem iparosok is, ahogy erre Paczona József budapesti cipész felesége adott példát 1894-ben. Ezen adatok fényében nem látom igazoltnak Pintér Jenő azon megállapítását, amely szerint a Magyar Bazár a fơvárosi nővilág müveltségét támogatta volna. ${ }^{31}$

A boríték olvasói reagálásaiból kiderül, hogy egyesek visszavonultak időnként, bár továbbra is előfizettek, de nem vettek részt a nyílt rovatokban folyó társalgásban, vagy kihagytak valamennyi időt az előfizetésben, és később tértek vissza újból lapjukhoz. Voltak olyanok is, akik évtizedeken át kitartottak a $M a-$ gyar Bazár mellett. A szerkesztői postából, illetve a nyílt levelezésből szemezgethetünk olyan jeligés álneveket, amelyek erre utalnak: „Egy hü előfizető”, „Tíz éves előfizető”, „a Bazár régi barátnője”, „28 év óta a Bazár előfizetője” stb.

Bresztovszky Edéné Gryneus Vilma például állhatatos olvasónak tünik, pedig többször váltott lakhelyet a kimutatás szerint: 1878 (Rimaszombat), 1888-1889 (Nagyvárad), 1899-1900 (Máramarossziget). ${ }^{32}$

Kadić Auguszta költözése után szintén megtartotta a Magyar Bazárt, vagy visszatért hozzá (Oriovac 1883, Kostanjevac 1888-1889). Édesapja Forkly János ópazovai postamester volt, és egy horvát nemzetiségü, határszéli közigazgatási

${ }^{30}$ VAJDA Viktor, Az olvasásról, különös tekintettel postáink járására = Figyelö, 1875, 47, november 21., 553-554.

31 Pintér Jenö Magyar irodalomtörténete, Tudományos rendszerezés VII, A magyar irodalom a XIX. század utolsó harmadában, Bp., Magyar Irodalomtörténeti Társaság, 1934, 772.

32 Fiai emlékezetében is nyomot hagyott a lap. Ernő (1882-1922) és Ede (1889-1963) később a Népszava munkatársai lettek. Kettejük közül feltehetően - a színházi előadásokról és frissen megjelent könyvekről is beszámoló - fiatalabbikhoz köthető az a két kritika, amelyek ironizálva angol társasági regényein és körkérdésein hivatkoznak a Magyar Bazárra. be [BRESZTovszky Ede?], Ne váljunk el (Pinero 3 fölvonásos vígjátéka. Bemutató előadás a Nemzeti Színházban) = Népszava, 1912, 236, október 5., 8.; ky. [BreszTovszky Ede?], Új magyar regények. Az égö Pannónia = Népszava, 1937, 265, november 21., 10. 
tiszthez ment feleségül, aki Oriovácon kilenc évig szolgabíróként dolgozott, az ő fiúkként született Kadić Ottokár geológus, paleontológus. A tudós visszaemlékezéséből tudható, hogy édesanyjának fontos volt magyarsága, és ebben a szellemben nevelte gyermekét. Szintén ő számol be arról, hogy elemi iskolás korában a Forgó bácsi [Ágai Adolf] Kis Lapját, középiskolás korában pedig az Ifjúsági Lapot járatta számára édesanyja. ${ }^{33}$ Ez azt sugallja, hogy Kadić Auguszta odafigyelt mind a család, mind a saját sajtófogyasztására.

Az 1878-as és az 1879-es évfolyamból három nevet emelek ki a borítékról, csupán jelezve, hogy milyen közegekben fordult elö a Magyar Bazár. Azonosításukat a teljes név és a mellette feltüntetett település tette lehetővé. Gerevich Emilné Ilniczky Ilona, Gerevich Tibor müvészettörténész édesanyja akkoriban Máramaroson élt férjével, akit 1877-ben a helyi felső leányiskola rendes tanárává neveztek ki. Uray Margit 1879-ben 19 éves volt, és férjével, a Szatmár megyei tiszti föügyész Kaffka Gyulával Nagykárolyban lakott. Egy évvel később, 1880ban született közös gyermekük, Kaffka Margit. Benedek Zsuzsa Benedek Elek unokatestvére volt, és a háromszéki Karatnán élt családjával. Az író nagybátyja a helyi református lelkész volt. Benedek Elek visszaemlékezéseiben arról írt, hogy a papnak kitünő könyvtárában találkozott először Schiller és Goethe müveivel, valamint ott forgatta a Vasárnapi Újság, a Magyarország és a Nagyvilág bekötött számait. Sőt, némi információt kapunk a lányok neveléséről, amit maga az apa és egy lengyelországi német lány, Jozefin vezetett. Benedek Elek múvelt lányokként jellemezte unokatestvéreit. ${ }^{34}$

A Magyar Bazár borítékán, a talányok megfejtői és a kérdés-felelet rovatok résztvevői között felbukkannak még testvérek, könyvkereskedések, apácarendek (sátoraljaújhelyi irgalmas nővérek), oktatási intézmények (leányiskolák, szakolcai ipartanoda), vagy más testületek (székesfehérvári Magyar Földmüves szerkesztősége). Szerepelnek kis számban férfinevek. Erre példa a tiszafüredi református tanító Milesz Béla agilis szervező, író, szerkesztő, több lap, mint például a Fövárosi Lapok vagy a Képes Családi Lapok munkatársa. Üzleti célra használta a nyílt rovatokat, könyveket árusított.

A középosztály és a nagyszámú falusi előfizető jelentősége abban is megmutatkozik, hogy a Magyar Bazár német és magyar társaihoz képest drága lapnak minősültt. ${ }^{35}$ Tehát kifejezett akarat állt az előfizetés mögött, ami a tartalomnak szólt, vagyis azt érezte az olvasó, hogy megéri számára.

33 SzÉKEly Kinga, Kutatás - küzdelem, siker - megaláztatás,. Adatok Kadić Ottokár munkásságához és a bükki ösemberkutatás történetéhez, ismeretlen kéziratok alapján = A Suba-lyuk barlang, Neandervölgyi ösember a Bükkben, szerk. Baráz Csaba, Eger, Bükki Nemzeti Park Igazgatóság, 2008, 138.

34 BENEDEK Elek, Édes anyaföldem! Egy nép s egy ember története (1920) (http://mek.OSZK. hu/05800/05867/05867 htm)

35 Wajdits Károly pápai könyvkereskedő hirdetésében összehasonlíthatjuk az árakat: Magyar Bazár és Budapesti Bazár (10 Frt/év), Bazar (8 Frt/év), Modenwelt (4 Frt/év), La Saison (6 Frt/év), Moniteur de la mode (13 Frt 80 korona/fél év). Pápai Lapok, 1878, 39, szeptember 29., 4.; 1889-ben 


\section{Közönségkapcsolat}

A szerkesztők érdekeltek voltak abban, hogy minél több körön kívüli olvasót kapcsoljanak be az előfizetői rendszerbe. Hiszen, ahogy a Wohl-nővérekkel kötött szerződésből is látszik, bizonyos határ felett jutalékot kaptak minden új fö után, bizonyos határ alatt pedig veszélybe került az állásuk. ${ }^{36}$ A létszámgyarapodást a különféle kedvezményeken és szolgáltatásokon keresztül igyekezték elérni. Az előfizetői jegyzékben szereplők kapták a lapszámokhoz tartozó állandó és alkalmi mellékleteket. Ez a Magyar Bazár esetében minta- és kézimunkalapokat, kottákat, lámpaernyőt, fénykép keretet, almanachokat jelentett. Továbbá az előfizetési címszalag beküldésével lehetett részt venni a jutalomjátékokon és a pályázatokon, használni a levelező rovatokat (grafológia, orvosi tanácsadás, nyílt tér), véleményt nyilvánítani a lapban felvetett témákban, közlésre szánt szövegeket, megbízásokat és személyes kérdéseket eljuttatni a szerkesztőséghez, illetve az előfizetési címszalag felmutatásával vásárolhattak jutányosan bizonyos üzletekben. Jellemzően a divatlapok az előfizetőket is bevonták a terjesztésbe, bizonyos számú új tag szerzése után a lap tiszteletpéldányát vagy egyéb kisebb nyereményt kaptak (könyv, nyomat).

Az 1890-es évek közepétől megjelentek az olyan könnyed, magánéletet érintő körkérdések, mint „Hosszú, vagy a rövid mátkaság a jobb?” vagy „Milyennek gondolja a férfi ideált?". A rovat az olvasóközönség mulattatásán és megmozgatásán túl azt a gyakorlati célt szolgálta, hogy fenntartsa az érdeklődést a lap iránt, erősítse a közösségi élményt, és új előfizetőket toborozzon. Az olvasói aktivitás többféleképpen megnyilatkozhatott, nemcsak válaszolhattak, hanem maguk is javasolhattak kérdéseket, emellett a legjobbnak ítélt beküldőkre is lehetett szavazni. Ezenkívül a Magyar Bazárban olyan a kor sajtójából jól ismert szerzőktől is kértek és adtak közre válaszokat, mint Adorján Sándor, Bartók Lajos, Büttner-nővérek, Dessewffy Arisztid, Justh Zsigmond, Kisfaludy Atala, Pekár Gyula, Szalay Fruzina, vagy olyan politikusoktól, mint Apponyi Albert vagy Szilágyi Dezső. ${ }^{37} \mathrm{~A}$ körkérdések gyakorlatát külföldi lapoktól vették át a hazaiak, sőt előfordult, hogy magukat a kérdéseket is, a Budapesti Bazár egyik alkalommal a londoni Womant jelölte meg forrásként. ${ }^{38}$ Más magyar képes hetilap, így $A$ Hét

a Budapesti Bazár, 1890-ben a Magyar Bazár 8 Frt-ra mérsékelte az éves előfizetés díját. A Divatsalon viszont egy évre 6 Frt-ba került 1890-ben.

${ }^{36}$ Ha az előfizetők száma 2700-ig fogyna, azon esetben az Athenaeumnak jogában áll, negyedévi határidőre felmondani a szerkesztőknek. Viszont, ha az előfizetők száma 4000 fölé emelkedik, a 4001-ik elöfizetőtől kezdve minden további új előfizető után osztalék gyanánt 10 krajcárt kapnak a szerkesztők, havonként utólagosan kiszolgáltatva. A Wohl-nővérek szerkesztői szerződése (1873. aug. 23.). 153. i.sz. 1873-1901., 2. cs., Z 1508 Gazdasági Levéltár, MNL

${ }^{37}$ Szilágyi Dezső társaságban megemlítette, hogy Wohl Jankától litografált levelet kapott, amelyben a nők kacérságáról való véleményét kérdezte. Nem ért rá neki válaszolni, de ott, a körülötte állóknak kifejtette ezzel kapcsolatos nézetét. Prém József, Két nap Szilágyival = Fövárosi Lapok, 1894, 286, október 16., 2454-2455.

38 „Inkább lenne-e neje olyan férfinak, akit szeret, de akinek viszontszerelméről nem biztos, 
is előszeretettel használta ezt a típusú rovatot, megpályáztatta olvasói körében, hogy ki a kedvenc Hét-szerzőjük (1892), híres emberektől származó aforizmákat tettek közzé (1892), illetve olyan klasszikus körkérdéseket tettek fel, mint „Illik-e a kártya az asszony kezébe" (1896).

Szintén az olvasóközönség érdeklődésének felkeltését szolgálták a különféle irodalmi pályázatok. A Magyar Bazár 1899 nyarán hirdetett tematikailag kötetlen novellaversenyt. A kiírás szerint három jeles, de meg nem nevezett író bírálta el a beérkező pályamunkákat. Az első három helyezett tárgyjutalomban részesült, illetve müveiket publikálták a lapban. ${ }^{39}$

Mindezek mellett a divatlapok rendszerint lebonyolítottak jótékonysági akciókat (felhívásokat tettek közzé, pénzadományokat gyüjtöttek és továbbítottak), valamint különféle mozgalmakat indítottak el, vagy csatlakoztak hozzájuk (a Magyar Bazár esetében pl. nemzeti ipar támogatása, nőipar felkarolása, leánygimnázium eszméje, a Magyar Békeegyesület segítése). A divatlapok kulturális téren is mozgósították olvasóikat, erre nyújt példát a Magyar Bazár közremüködése az 1893-ban meghirdetett Jókai-év ünnepségsorozatában. Wohl Janka ötlete nyomán a Magyar Bazár azt a felhívást intézte olvasóihoz, hogy egy szmirnai szőnyeget adjanak ajándékba az írónak, amelynek minden kockáját más-más nő készít el; kedvcsinálóként felsorolták a kezdeményezéshez csatlakozó illusztris személyek, többek között Arany Lászlóné, Berzeviczy Albertné, Csáky Albinné, Emich Gusztávné, Munkácsy Mihályné, Wohl Janka neveit. ${ }^{40}$ A kivitelezés módja a következő módon zajlott: április 25 -ig kellett jelentkezni a szerkesztőségben névvel és pontos lakcímmel, majd május végéig az aláírók kezéhez jutott a megkezdett munka. Július közepéig várták vissza az elkészült darabokat Fürth Lajosnéhoz, aki összedolgozta a részeket. Végül több mint nyolcvan nő müködött közre a szőnyeg létrehozásában. Az ünnepség kezdetéig a Gizella téri

vagy olyan férfinak, aki önt szereti, de akinek szerelmét nem viszonozhatja teljesen?”. Budapesti Bazár, 1892, 14, július 15., boríték. A Figaro irodalmi mellékletének körkérdéseiröl lásd VérILHAC, Yoan, „Les femmes seules savent écrire une lettre”: sur le „Questionnaire” du Figaro de l'année $1888=$ La lettre et la presse : poétique de l'intime et culture médiatique, szerk. Guillaume Pinson, Médias 19 (http://www medias19.org/index.php?id=329)

39 A pályázat eredményeként az első helyezett Vécseyné Jankovich Lujza (Noémi levelei), a második Tutsekné Bexheft Lilly (Nicokris), a harmadik Westersheimbi Wettstein Jenőné (Büntetés). Díjak: korsó alakú, íróasztalra való óra, szecessziós bőrmappa és TEGNÉr, A Frithiof-monda (ford. Győry Vilmos). Magyar Bazár, 1899, 47, december 16., 100. Az első két szerző neve ismerős lehetett a korabeli olvasók számára, mert rajzaikkal, tárcáikkal már találkozhattak, például a Pesti Napló, Képes Családi Lapok vagy a Fövárosi Lapok hasábjain. A harmadik nyertes előzetes írásos tevékenységéről nem találtam adatot.

40 Felhívás a magyar nőkhöz! = Magyar Bazár, 1893, 8, április 16., 58; Más lap is indított hasonló mozgalmat előfizetői körében. A Magyar Háziasszony nevében Komócsy József Beniczkynének nyújtott át 25 éves írói jubileumára aranytollat, amit az előfizetők adtak össze. Andrea, $A z$ aranytoll átnyújtása = Magyar Háziasszony, 1886, 51, december 19., 2; Arany Lászlóné és Hampel Károlyné felhívására értelmiségi és arisztokrata feleségek maguk készítette szőnyeggel lepték meg Gyulai Pált írói jubileumán. Az Évszak 1895, 6, március 16., 24. 
Haas-szőnyegkereskedés kirakatában állították ki a munkát. Az átadási ceremóniáról, amely 1894. január 5-én délben történt meg, a magyar sajtó is beszámolt. ${ }^{41}$

Tehát az anyagi juttatásokon túlmenően a jól szerkesztett lap azzal az érzéssel ajándékozhatta meg az előfizetőt, hogy egy közösség soraiba lép. A női magazinok amellett, hogy a nemzeti közösség kereteit müködtették, olyan virtuális közösséget hoztak létre, amelyet a lap és az olvasók, illetve az olvasók egymás közötti intenzív levelezése idézett elö. ${ }^{42}$ Így a retorikailag létrejövő „mi” magába foglalta az olvasót, a munkatársat, a szerkesztőt. A Magyar Bazár is előszeretettel élt különféle valódi és fiktív levelek közzétételével, amelynek fesztelensége és személyessége jól illett a divatlap arculatába, amely bizalmas, meghitt hangulatot sugárzott. Wohl Janka a szükebb-tágabb ismeretségi köréből kapott levelekből külföldi tudósításokként vagy útirajzokként szokott közreadni részleteket, így Angliáról, Amerikáról vagy Nizzáról olvashattak az előfizetők: „Egy kis barátném (titokban a nevét is megsúgom: Földváry Emma) oly érdekesen írta le a napokba úti élményeinek egy részét, hogy valóságos bünnek tekinteném, ha egyedül magamnak tartanám a sok, változatos szép dolgot, mit élveznie megadatott néki. Nem is változtatok semmit a lendületes sorokon, hadd beszéljen ő maga". ${ }^{43} \mathrm{~A}$ levél ilyetén szerepeltetése kettős funkcióval ruházza fel a müfajt, közérdekű cikk és magándokumentum egyszerre, amely játékba hozza a személyes és nyilvános tereket. ${ }^{44}$ Másrészt a levelek beemelése közvetetten a szerkesztő rangját emelte, mutatva milyen elökelö és nemzetközi összeköttetésekkel rendelkezik.

A Magyar Bazár, miközben professzionális munkatársi gárdával rendelkezett, a fesztelen, baráti közegre helyezte a hangsúlyt, amely révén az újságíró az olvasó önzetlen társalkodójaként tünt fel. Példa erre Aladin Kiállítási levelek címü helyszíni szemléje az 1885-ös országos kiállításról: „Szerencsémre a »Magyar Bazár « mint női lap, olyan közönséggel bír, mely szívesebben veszi az önként és hódolatteljes készséggel nyújtott keveset, azon soknál, mit talán szakavatottabb, de már a munka kényszerúsége folytán is elkedvetlenített igazi, hivatalosan megerösített reporter nyújthatna". ${ }^{45}$

Ahogy a fenti idézetből is kiviláglik, a női lapok a bizalmas és családias viszony kialakítására és fenntartására törekedtek az olvasókkal, amely viszony

${ }^{41}$ A Jókai-ünnep = Magyar Bazár, 1894, 2, január 16., 14; A Magyar Bazár Jókai-akciójáról lásd Rózsafalvi Zsuzsanna, ,, Ötvenéves aranylakodalom a múzsával”, A Jókai-jubileum és a díszkiadás története $=$ Budapesti Negyed, 2007, 4, 335-359.

${ }^{42}$ A virtuális közösség fogalmáról lásd RHEIngold, Howard, The Virtual Community; Homesteading on the Electronic Frontier, New York, Addison-Wesley, 1993. A virtuális közösség és a női magazinok összekapcsolásáról lásd SEnEcA, Tracy, The History of Women's Magazines, Magazines as Virtual Communities (http://besser.tsoa nyu.edu/impact/f93/students/tracy/tracy_hist html)

${ }^{43}$ Két levél = Magyar Bazár, 1895, 34, szeptember 8., 135.

${ }^{44}$ Vö. VaILlant, Alain, Le double jeu du journal, entre communication médiatique et correspondance privée $=$ La lettre et la presse $:$ poétique de l'intime et culture médiatique, szerk. Guillaume Pinson, Médias 19 (http://www medias19.org/index.php?id=341)

${ }^{45}$ Aladin, Kiállitási levelek = Magyar Bazár, 1885, 10, május 16., 79. 
a kölcsönösség és a személyesség érzésén alapult. ${ }^{46} \mathrm{Az}$ olvasók tömegével fordultak levélben a szerkesztőséghez kérdéseikkel, kéréseikkel, pályázataikkal, vallomásaikkal, amelyeket fel kellett dolgozni, válaszolni rájuk. A szerkesztőség felé áradó bizalom sokszor zavarba ejtette a munkatársakat, hiszen olyan részleteket fedtek fel előttük, amikről még az illető legközelebbi hozzátartozói sem biztos, hogy tudtak. Ezt az az egyéni meggyőződés alapozta meg, miszerint a lap megérti őt, hozzá szól: ,»Mintha csak a saját gondolataimat olvasnám, olyan igaz, amit a t. Szerkesztőség ebben s ebben a cikkében kifejt...« írja időnként egy-egy hủ olvasó". ${ }^{47}$

A szerkesztőségnek címzett levelek, publikálásra szánt szövegek beküldése, a lap különböző felhívásaihoz való csatlakozás mellett, a divatlapok nyílt tér rovatai nyújtottak ösztönző lehetőséget az előfizetői megnyilvánulások számára.

\section{Nyillt tér}

Kármán József és szerkesztőtársa, Pajor Gáspár még azzal a szándékkal bocsátotta útjára az Urániát (1794-1795), hogy a női olvasó társalkodója legyen. Egy későbbi nőknek szánt almanach címe, a Gyönyörködtető társ (1812), szintén személyes párviszonyt fejez ki. Ez a kettőségen alapuló kapcsolat megtöbbszöröződik a 19. század folyamán, és már egy körben találja magát a női olvasó. Az újságolvasás nemcsak a vidék és a főváros, hanem az ország különböző pontjai között is kommunikációt létesített. Martyn Lyons úgy fogalmaz: „Az olvasásnak fontos szerepe volt a nők társasági életében". ${ }^{48}$

A 19. századi napilap, ahogy erről korábban már volt szó, a kávéház, az áruház és a parlament képeivel fonódott össze. A divatlapok, bár címeik gyakran kereskedelmi helyszínekre utalnak (bazár, divatcsarnok), a szalon retorikáját müködtetve teremtették meg hasábjaikon a szövegek referenciális keretét. A divatlapok és a női társaskörök összekapcsolása már a reformkorban jelentkezett. A Regélő Pesti Divatlap szerkesztői előszava a „lelkesebb honleányaink, sőt finomabb úrhölgyeink $\mathrm{s}$ a pamlagkörök méltánylását" tüzte ki célul. ${ }^{49} \mathrm{~A}$ női divatlapok virtuális szalonként való önmeghatározása megmutatkozik a lapok beszédstratégiáiban. A Budapesti Bazár „Fővárosi szemle” című tárcarovatában

46 Vö. Ballaster, Ros, Beetham, Margaret, Frazer, Elizabeth, Hebron, Sandra, Women’s Worlds, Ideology, Femininity and Women's Magazines, London, Palgrave Macmillan, 1991; Beetham, Margaret, Magazine of Her Own? Domesticity and Desire in the Women's Magazine, 1800-1914, London, Routledge, 1996; Victorian Women's Magazines, An Anthology, szerk. Margaret Beetham, Kay Boardman, Manchester, Manchester University Press, 2001.

${ }^{47}$ A mi levelezőink = Magyar Bazár, 1898, 1, január 1., boríték

${ }^{48}$ Lyons 2000, i. m. 355; A magyar női olvasókról lásd A zsoltártól a rózsaszín regényig, Fejezetek a magyar női müvelődés történetéből, szerk. Papp Júlia, Bp., Petőfi Irodalmi Múzeum, 2014.

${ }^{49}$ Idézi FerenCZy József, A magyar hírlapirodalom története 1780-tól 1867-ig, Bp., Lauffer, $1887,433$. 
1884 nyarán szerzőváltás történt, a Komócsy Józsefet követő Király Kálmán első írása a lap imaginárius terébe való szimbolikus belépéssel kezdődik: „Kopogtatok. Semmi hang, semmi felelet. Kopogtatok újra, s egy vontatott »szabad« után belépek nagysádtok kedves salonjába" ${ }^{50}$ A Magyar Bazár 1893-as évfolyamra szóló előfizetési felhívása szintén bensőséges kört érzékeltet: „Midőn lapunk huszonnyolcadik évfolyamára indul, nem bocsáthatjuk útnak anélkül, hogy régi hü olvasóinkat a viszontlátás örömével ne üdvözöljük és új barátainknak fogadására ne siessünk. (...) Régi kedves társaságot találunk együtt, hazánk előkelő családainak színe-javát...". ${ }^{51}$

A 19. század második felében a divatlapok rovataikkal elősegítették az országos női hálózatok kialakulását mégpedig úgy, hogy magukra öltve a szalon képét, a találkozásnak, a társalgásnak, üzleti és kulturális cseréknek biztosítottak teret. Mindez a divatlapok borítékán található nyílt rovatokban bontakozott ki a legerösebben, ahol az előfizetők olvasnivalókat, kottákat, szépségápolási, háztartási, öltözködési tanácsokat, nótákat, szerencsehozó rigmusokat (30-szor, 300-szor elmondandó imák, szerelmi hiszekegy stb.) csereberéltek egymás között, árultak, vagy családtagokat, hajdani iskolatársakat, levelezőpartnereket kerestek. Illetve a rovaton belül különböző témákban beszélgető csoportok alakultak ki. Általános az álnév-használat (pl. Havasi gyopár, Kék nefelejts, Erdők csalogánya, Kis hamis...). Jellemzők a résztvevők által használt rituális szófordulatok: belépés a körbe, a bekopogás (átlépni a küszöböt), a bemutatkozás, a meghívás, a gardedámkérés, az elbúcsúzás. ${ }^{52}$ Továbbá rendeztek királynőválasztásokat a rovatban, de előfordult az is, hogy az elhunyt társnőikre emlékeztek meg. A résztvevők az adott lap borítékának színe után nevezték el a nyílt teret rózsaszín- vagy éppen zöld szalonnak. Elejtett megjegyzéseik alapján arra lehet következtetni, hogy nemcsak egy „társalgó”-ban fordultak meg. Bár tiltották, de a kipattanó botrányokból kiderül, hogy az álnevek takarásában férfiak is részt vettek a nyílt levelezésekben, vagy tréfából, vagy ismerkedés céljából; a rovatnak többek között ezért volt rossz híre.

A Budapesti Bazárban megjelent cikk elbeszélője egy kedves ismerősének kezében meglátta a Budapesti Bazár bekötött számait. Lapozgatott bennük, és csodálkozva látta, hogy az illető a borítékot is beköttette. Kérdésére, hogy miért, ezt a feleletet kapta: „Halálos bün volna azt elvetni, nemcsak azért, mert ezer

${ }^{50}$ KIRÁly Kálmán, Fơvárosi szemle = Budapesti Bazár, 1884, 14, július 15., 111.

${ }^{51}$ A „,Magyar Bazár” olvasóihoz = Magyar Bazár, 1893, 1, január 1., 1.

${ }^{52}$ Itt érdemes megemlíteni Walter J. Ong az elektronikus technológia (telefon, rádió, tévé) kapcsán kifejtett „másodlagos szóbeliség” elméletét (Orality and Literacy, 1982): „Az új szóbeliség feltűnő hasonlóságokat mutat a régivel: részvételi misztikájában, a közösségi érzés fokozásában, a jelen pillanatra történő összpontosításában, még az állandó fordulatok használatában is [...] de lényegét tekintve ez akartabb és tudatosabb szóbeliség, mely állandó jelleggel az írás és nyomtatás használatára alapozódik". Idézi NYíri Kristóf, Bevezetés, Adalékok a szóbeliség-írásbeliség paradigma történetéhez = Szóbeliség és írásbeliség, A kommunikációs technológiák története Homérosztól Heideggerig, szerk. Nyíri Kristóf, Szécsi Gábor, Bp., Áron, 1998, 15. 
hasznos dolgot foglal magában, oktat, tanít, szórakoztat, hanem a sok gyakorlati jó tanácsokon és konyhai főzőcédulákon kívül még kedélyes csevegésein is mulatok, valósággal beleképzelem magamat ebbe az úgynevezett »rózsaszín szalon«-ba, ahol néma tanúja vagyok az ismeretlenek társalgásának". ${ }^{33}$

A divatlapok igyekezték szabályozni kisebb-nagyobb szigorral a rovatot, erkölcsi és az irodalmi színvonalra hivatkozva, illetve megbirkózni az óriási közönségigénnyel. A Magyar Bazár a következö témákat engedélyezte a nyílt rovatokban: irodalmi, tudományos, müvészeti, háztartási, konyha, toalett, közérdekủ vagy közhasznú. Orvosi, személyes vagy családi vonatkozású leveleket, magánlakcímeket firtató kérdéseket, illetve olyan költeményeket, dalokat, amik már elavultak, nem közöltek. ${ }^{54}$ Létezett átjárás a boríték és a lap törzsanyaga között, amit átkerült felhívások, témák bizonyítanak. ${ }^{55} \mathrm{~A}$ Magyar Bazárban Székely Ilona így írt a nyílt térről: „Magam is átfutom hűségesen, mert azt tartom, hogy legbiztosabb hőmérője az olvasóközönség ízlésének, igényeinek, müveltségi fokának - s ez mindenesetre megérdemli, hogy figyelemmel kísérjük". Mindazonáltal Székely hiányolta a felmerülö témák sokféleségét, mondván, míg az angolok, franciák nemcsak a kézfehérítö krém, hanem a legmüvészibb tapéta vagy zenedarab után sem restek tudakozódni. ${ }^{56}$

A Magyar Bazár nyílt rovataiban azért felmerültek komolyabb témák is. Visszatérően érdeklődtek különböző képzések, hivatások, állások iránt, vagy jótékonysági felhívásokat köröztettek. Az egyik előfizető abban kért segítséget, hogy hogyan kell megírni egy egyleti beszédet, ami rávilágít a nők közéleti szereplehetőségeire, és a kevéssé vizsgált női szónoklatokra. Azt ajánlották neki, hogy egy politikai napilap régebbi számaiból keressen ki egy efféle gyülés megnyitójáról szóló beszámolót, mintának a Vöröskereszt éves közgyülését említették, majd röviden leírták a beszéd szerkezeti felépítését. ${ }^{57}$ Továbbá folytak diszkussziók a cselédekről vagy a füzőviselésről. A nóták tömegei között komolyabb olvasmányok is gazdát cseréltek, így például Kadić Auguszta Az ember tragédiáját kérte társaitól. ${ }^{58}$

A nyílt terek a korabeli kritika kereszttüzében álltak. Senex Pesti Hirlapban megjelenő tárcája kipellengérezte egy meg nem nevezett képes hetilap levelezési rovatát. A szerzőt megdöbbentette az „Előfizetők postája” rovat, szörnyülködött az álneveken és a kérelmeken, például azon, hogy az adott irodalmi müvet - megvétel helyett - másolatban és gyakran csak részleteit kérik. Senex szerint a szerkesztő üzleti megfontolás miatt hagyja meg a nyílt rovatot, nehogy elveszítsen

${ }^{53}$ Margit, A rózsaszín szalon = Budapesti Bazár, 1885, 22, november 15., boríték

${ }^{54}$ Magyar Bazár, 1875, 24, december 16., boríték

55 Példa erre az Egy anya álnév alatt, a lap fó részében megjelent Levél egy kedélybeteghez című írás, amely reflektált a Magyar Bazár azt megelőző számának borítékján közölt Zsoica kérdésére, aki gyógymódot kért lelki betegségben szenvedő nő számára. Magyar Bazár, 1883, 11, június 1., 86-87.

56 SzÉKelY Ilona, A zöld boriték = Magyar Bazár, 1894, 7, április 1., 55.

${ }^{57}$ Nyílt posta, Egy az újak közül-nek = Magyar Bazár, 1893, 1, január 1., boríték

${ }^{58}$ Magyar Bazár, 1889, 3, február 1., boríték 
előfizetőket: „Hát odajutottunk már, hogy egy magát szépirodalminak hirdető lap szerkesztője, ahelyett, hogy vezetni igyekeznék olvasóit, csak dédelgeti azok gyöngeségeit s alkalmat nyújt nekik, hogy primitív szórakozásaikhoz a közügyeket szolgáló sajtó segítségével keressenek naiv társakat?"59

Ahhoz, hogy egy divatlap meg tudja őrizni olvasóközönségét, azt nagyban köszönhette azoknak a rovatoknak, amelyekben megnyilvánulhatott az előfizetők aktivitása. A nyílt terek nagyfokú népszerűsége és forgalma a szórakozás mellett az információszerzés igényére mutat. Ha elfogadjuk McLuhan kijelentését, hogy a napi sajtó alapja az apróhirdetés és a tőzsde, akkor a divatlapnál ez a nyílt tér. A kanadai médiatudós szerint a „könyvember” idegenkedik a hirdetésektől, és szeretné azokat számúzni lapja hasábjairól, valójában az újságolvasó tekintet ugyanolyan elégedetten időz a hirdetéseken, mint a híreken. ${ }^{60}$ Parafrazeálva McLuhan bonmot-ját, miszerint a hirdetések voltaképp hírek, a nyílt tér voltaképp nem más, mint hírfolyam, amelyben személyes, kulturális, gazdasági információk keverednek egymással.

Olvasói attitüdök, preferenciák, fogyasztási szokások és a mentalitás tanulmányozására éppen emiatt kiválóan alkalmasak a nyílt terek, de az olvasáskutatások számára is szolgálhatnak tanulságokkal. A könyvtörténészek a materialitást hangsúlyozva, a könyv kommunikációs modelljét veszik alapul, amelyek következtében az olvasásnak, mint könyv-egyén között zajló belső folyamat kutatásának tulajdonítanak kitüntetett szerepet. ${ }^{61}$ A divatlapok nyílt tereinek résztvevői amellett, hogy a hálózat felé nyitják meg az olvasáskutatásokban rögzült pár-modellt, a szöveghasználat más módjaira irányítják a figyelmet: másolás, kivágás, elküldés, hozzáírás, kivarrás, beragasztás.

E rovatoknál jól hasznosítható az az értelmezői eljárás, amely a történeti megközelítést a jelennel nyitja össze. Briggs és Burke jegyezte meg, hogy néhány jelenség régibb, mint ahogy általánosan gondolják, például a tévésorozatok a rádiósorozatokon, azok pedig a 19. századi tárcaregényeken alapulnak. ${ }^{62}$ Michael Pickering az új médiumok felöl indított történeti megközelítésre biztat, amely segítségével megérthetjük az új médiumokban azt, hogy mi bennük a régi, a régiekben pedig azt, hogy mi bennük az új. ${ }^{63} \mathrm{~A}$ hazai szakirodalomban is találunk erre példát, Dede Franciska $A$ Hét 1901-es receptpályázatának folyamatát a bloghoz

59 Senex [Lasz Samu?], Az én zöld lapom = Pesti Hirlap, 1890, 269, szeptember 30., 3; A cikkben meg nem nevezett lap feltehetően a Képes Családi Lapok lehetett, mert zöld volt a borítéka, és ez az újság reagált leghevesebben az írásra.

${ }^{60}$ McLuhan, Marshall, Understanding Media, The Extensions of Man, kritikai kiadás, szerk. W. Terrence Gordon, Corte Madera, Gingko Press, 2003 [1964], 282.

${ }^{61}$ Nerone, John, The Future of Communication History = Critical Studies in Media Communication, 2006, 3, 257.

62 Briggs, Burke 2012, i. m. 12.

${ }_{63}$ Pickering, Michael, The devaluation of history in media studies = The Routledge Companion to British Media History, szerk. Martin Conboy, John Steel, London, Routledge, 2015, 12. 
hasonlította. ${ }^{64}$ Mindezek fényében a nyílt terek müködése és funkciója párhuzamba hozható a mai online közösségi oldalak bizonyos szerveződési sajátosságaival: álneves (nickname) kommentelők, témák szerint szerveződő fórumok. Bár többszörösen közvetett a folyamat - a levelek beérkezése, szortírozása (moderálása), sorrendberakása, közlése -, amelynek következtében a hozzászólások késnek, esetleg kimaradnak, mindezen esetlegességek dacára a nyílt terek retorikája az egyidejüséget idézi. Kis csoportokban zajlanak különféle beszélgetések, szabadon lehet hozzájuk csatlakozni vagy kilépni belölük, figyelemmel kísérni a meglévőket vagy újakat kezdeményezni. Tehát a divatlapok nyílt terein a női előfizetők között aktív, folyamatosan alakuló közösségi háló szövődött, amely révén levelezések, személyes találkozók, kapcsolatok, ügyletek bonyolódtak.

\section{MÉSZÁROS, ZSOLT}

\section{Réseaux féminins et revues de mode au 19e siècle}

\section{Le Bazar Hongrois et son public}

Dans mon article, je me propose d'étudier, selon la méthodologie des approches féministes et médiologiques mettant en valeur la complexité des rapports qui existent entre la sphère privée et la sphère publique, la revue de mode la plus illustre du dernier tiers du $19^{\mathrm{e}}$ siècle, le Bazar Hongrois. J'analyserai les rapports que les rédacteurs avaient établis avec les abonnés et aussi la façon dont les journalistes ont exploité les cadres de la publicité. J'examine aussi la composition sociale et la répartition géographique du public du Bazar Hongrois, ainsi que l'activité des lecteurs dans la rubrique qui leur est réservée. En guise de conclusion, je constate que les revues de mode de la seconde moitié du $19^{\mathrm{e}}$ siècle, par leur structure, par leur ton familial, par les rapports étroits avec les lecteurs et enfin par leur coopération avec quelques associations ont largement contribué à la formation de réseaux féminins. Les revues en question se définissaient comme salons : forums d'échanges culturels, de rencontres et de discussions de toutes sortes. L'analyse de la rubrique réservée aux lettres provenant des lecteurs permet également d'étudier les mentalités du public, ses habitudes de consommation, ainsi que les contraintes qui pèsent sur les rédacteurs.

Keywords: History of civilisation, 19th Century, Hungary, Press History, Women's Magazine, Fashion Magazine

${ }^{64}$ Dede Franciska, Tartsd jól a bestiát! Emma asszony (Ignotus) receptpályázata és A Hét szakácskönyve, Egy századfordulós „,blog” története, Bp., Kortárs-OSZK, 2010. 